\title{
腎性上皮小体機能㝋進症に対する上皮小体全摘出術と自家移植術
}

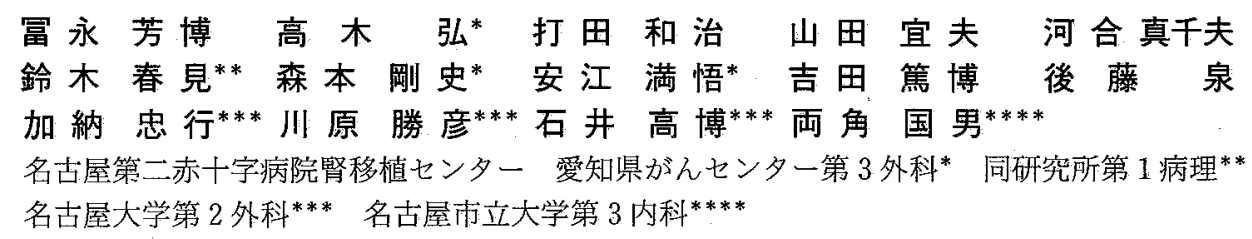

(昭和 57 年 10 月 14 日受付)

key words : hyperparathyroidism：上皮小体機能立進症, chronic renal failure：慢性腎不全, total parathyroidectomy：上皮小体全摘出術, parathyroid autotransplantation：上皮小体自家移植術, parathyroid hyperplasia : 上皮小体過形成

〈要旨〉

内科的治療に抵抗する高度な腎性上皮小体機能六進症には外科的治療が必要であり，われわれは, 31 例に上皮小体 摘出術を施行してきた，術後も腎不全状態が続く限り，残存腺への刺激は避けられず，再発は十分考慮せねばならな い. そこで, 最近の 11 例には, 従来よりの上皮小体亜全摘出術に变えて, 上皮小体全摘出術と摘出上皮小体の前腕筋 肉内自家移植術を施行した. 11 例は, 男 10 例，女 1 例で, 平均年歯 45.6 歳, 平均透析期間 92.0 力月であった。高上 皮小体ホルモン (高PTH) 11 例, 高アルカリフォスファターゼ (高Al-P) 9 例, 骨脱灰, 骨吸収像 11 例, 自覚症状 11 例, 高 Ca 血症 3 例であった. CT, echo, scintigram による画像診断で, 10 例に術前腫大した上皮小体を確認し， 手術適応決定に有用であった。手術は，Wells の方法に準じ，全摘出後，摘出上皮小体を小切片とし約 $50 \mathrm{mg}$ を前腕 筋肉内に移植し, 残りの一部を凍結保存した. 全例とも術後 $8 \sim 28$ 日目に, 移植側と対側の肘静脈のPTH 測定によ り生着を確認した。術後低 $\mathrm{Ca}$ 血症は著しく, 多量の Ca-gluconate, 乳酸 $\mathrm{Ca}, 1 \alpha \mathrm{OHD}_{3}$ を必要とした。自覚症状, $\mathrm{Al}$ $-P$, 骨X線像の改善は顕著であった，摘出総重量の平均は, $3415.3 \mathrm{mg}$ で, 組織像は diffuse type $47.7 \%$, nodular type $52.3 \%$ の過形成であった。 1 例に再発が見られ，術後 7 カ月と 10 カ月目に，局所麻酔下に腫大した移植上皮 小体の摘出術を施行した。移植腺の摘出総重量は $3914 \mathrm{mg}$ で, clear chief cell 主体の過形成像を示した. 本術式は, 1 ) 再発時の摘出が容易，2）移植腺の量の調節が可能，3）移植腺の機能の把握が可能などの点より再発の可能性 の十分存在する腎性上皮小体機能过進症の術式として優れている。

\section{Total parathyroidectomy and parathyroid autotransplantation in patients with chronic renal failure}

Yoshihiro Tominaga, M. D., Hiroshi Takagi, M. D.*, Kazuharu Uchida, M. D., Nobuo Yamada, M. D., Machio Kawai, M. D., Harumi Suzuki, M. D.**, Takeshi Morimoto, M. D.*, Mitsunori Yasue, M. D.*, Atsuhiro Yoshida, M. D., Izumi Goto, M. D., Tadayuki Kano, M. D.***, Katsuhiko Kawahara, M. D.***, Takahiro Ishii, M. D.***, Kunio Morozumi, M. D.****

Organ Transplant Center, Nagoya Second Red Cross Hospital, Department of Surgery III*, Department of Pathology, Aichi Cancer Center, ${ }^{* *}$ Department of Surgery II, Nagoya University***, and Department of Internal Medicine, Nagoya City University****

Total parathyroidectomy and autotransplantation to the forearm was undertaken in 11 chronic renal failure patients as treatment for secondary hyperparathyroidism. The indication for parathyroidectomy included hyperparathyroid hormone (PTH) in 11 patients, hyper-Alkaline phosphatase (Al-P) in nine, severe bone resorption in radiographic findings in 11 and such symptoms as bone pain, arthralgia, pruritis irritability, etc., in 11.

Preoperatively we recognized enlarged parathyroid glands by computed tomography, echography and ${ }^{201} \mathrm{TICI}$ 
scintigraphy in 10 patients. The preoperative visualization of enlarged parathyroid glands is valuable not only for the localization, but also for unequivocal evidence of hyperparathyroidism.

The mean weight of the total resected parathyroid glands was $3415 \mathrm{mg}$, and the pathological diagnosis was secondary hyperplasia in all cases. Autograft function 8 to 28 days after transplantation was demonstrated in all cases by differential PTH concentration determination.

All patients experienced symptomatic improvement after surgery and showed objective evidence of improved PTH, AI-P and radiographic findings of the bone. One patient required partial excision of hyperfuctioning tissue from the forearm because of recurring symptoms of secondary hyperparathyroidism and re-elevation of PTH. The hyperplastic tissues grafted in the forearm were easily removed under local anesthesia. The total weight of the removed tissues was $3914 \mathrm{mg}$, and the pathological diagnosis was clear chief cell hyperplasia. Therefore, we recommend total parathyroidectomy and autotransplantation for patients requiring surgical treatment for secondary hyperparathyroidism with chronic renal failure.

\section{緒言}

活性型 Vit $\mathrm{D}_{3}$ など内科的治療の進歩にもかかわらず， 内科的治療に抵抗し, 外科的治療を必要とする腎性上皮 小体機能六進症が增加しつつある。われわれは，その診 断, 外科的治療に努め, 31 例の腎性上皮小体機能六進症 例に, 上皮小体摘出術を施行してきた ${ }^{1,2)}$. 腎不全の根本 的治療がなされない限り, 術後にも残存腺への刺激は避 けられず, 再発は十分考慮せねばならない. 最初の 20 例 に上皮小体亚全摘出術を施行したが，再発例に遭遇した ので, 1980 年以降の 11 例には上皮小体全摘出術と摘出 上皮小体の前腕への自家移植術を施行した。 以下，上皮 小体全摘出と自家移植術の経験について報告する。

\section{対象}

1982 年 9 月までに, 31 例の腎性上皮小体機能立進例 に, 上皮小体摘出術を施行した。 31 例中，20 例に上皮小 体亜全摘出術を, 1980 年以後の 11 例に上皮小体摘出術 と自家移植術を施行した。上皮小体亜全摘出群 20 例 (男 14 例，女 6 例）の平均年齢 33.8 歳，平均透析期間 61.5 力月であった. 上皮小体全摘出と自家移植術群 11 例 (男 10 例，女 1 例）の平均年齢 45.6 歳，平均透析期間 92.0 カ月であった. 全摘と自家移植群では高齢かつ平均透析 期間も長期であった(表 1 ). 術前所見は表 2 のごとくで あった。亜全摘出群には， $1 \alpha \mathrm{OHD}_{3}$ 普及前の 1978 年以

\begin{tabular}{c|c|c|c}
\hline & 症例 & $\begin{array}{c}\text { 平均年齢 } \\
\text { (歳) }\end{array}$ & $\begin{array}{c}\text { 平均透析期間 } \\
\text { (月) }\end{array}$ \\
\hline 上皮小体亜全摘出 & 20 & 33.8 & 61.5 \\
\hline $\begin{array}{c}\text { 上皮小体全摘出 } \\
\text { 自家移植術 }\end{array}$ & 11 & 45.6 & 92.0 \\
\hline 計 & 31 & 37.0 & 72.3 \\
\hline
\end{tabular}

表 1 笽性上皮小体機能圥進症
前の症例が 8 例含まれ, 比較的軽度の腎性上皮小体機能 六進症例も含まれていた。全摘と自家移植群 11 例は，い ずれも高 c-PTH を示し，骨X線上骨膜下吸収像など典 型的な線維性骨炎所見を呈した。 なんらかの自賞症状も 全例で見られ, 骨関節痛 9 例, 頑固な搔㾕感 5 例, 筋力 低下 4 例, 不眠, イライラ感 5 例, 繰り返す消化性潰瘍 1 例であった. 高 Al-P は, 11 例中 9 例で見られ, アイ ソザイム解析の結果はいずれも骨パターンを示した. 11 $\mathrm{mg} / \mathrm{d} l$ 以上の高 $\mathrm{Ca}$ 血症を示した症例は, 11 例中 3 例存 在した。術前に頸部 CT, echo と ${ }^{201} \mathrm{TlCl},{ }^{99} \mathrm{~m}^{\mathrm{T}} \mathrm{CO}_{4}^{-}$によ る scintigram を施行し, 11 例中 10 例に術前上皮小体の 腫大を確認した。以上全摘と自家移植術を施行した 11 例 は,いずれも高度の腎性上皮小体機能六進症例であった。

\section{方法}

術式は Wells 等の方法に準じた ${ }^{3)}$. 頸部横切開にて, 広頸筋を含む皮膚弁を上方は甲状軟骨，下方は胸骨柄ま で形成した。 strap muscle を正中で縦切し, 甲状腺両側 面に到達した。 上皮小体 4 腺を同定し, 術中迅速標本に て上皮小体と確認後 4 腺を摘出した. 摘出腺のうち, 最 も過形成が軽度と思われる腺より $1 \times 1 \times 3 \mathrm{~mm}$ の小切片 を約 20 個作成した. 血液透析のためのシャント (blood access）のない方の前腕に約 $7 \mathrm{~cm}$ の縦切開を加え, 筋 膜縦切開後, 筋肉内にモスキート鉗子にてポケットを 作った．その中に，上皮小体小切片 1 個を入れ，筋肉を 4-0 編系にて縫合した. 同様にして 10〜20 個の上皮小体 小切片を自家移植した. 生着しない時を考え残った上皮 小体の一部を凍結保存した。すなわち, 上皮小体を小切 片とし, $10 \%$ dimethyl sulfoxide, $10 \%$ autologous serum, $80 \%$ Waymouthś tissue culture medium 内に入 れ, program freezer (Union Carbide 社製) を用い凍 結し，液体窒素内にて凍結保存した。術後は，摘出が十 分であったことを確認するため, 血清 $\mathrm{Ca} 7.0 \mathrm{mg} / \mathrm{d} l$ 以 


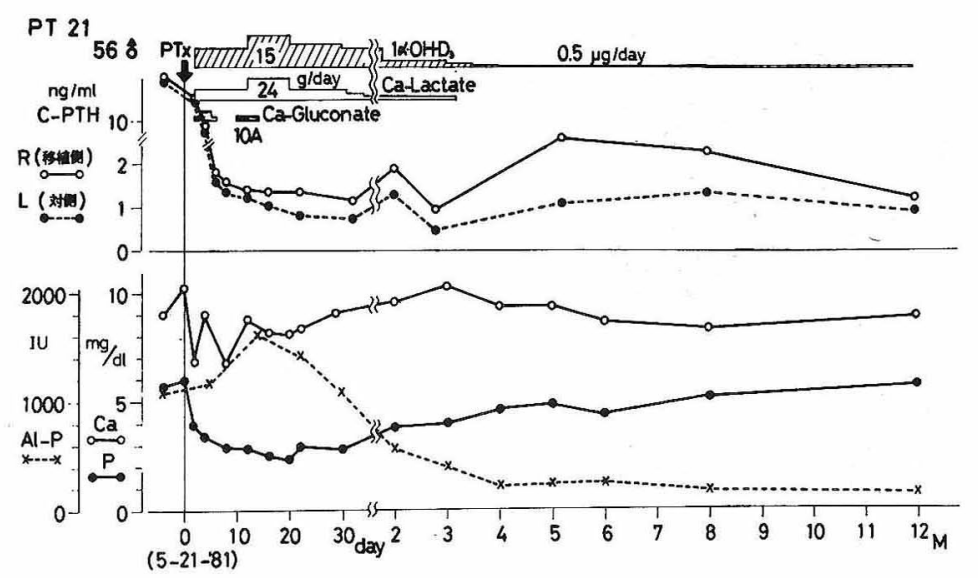

図 1 PT 21 上皮小体全摘出と自家移植術後の経過表

\begin{tabular}{|c|c|c|c|}
\hline 所 見 & $\begin{array}{c}\text { 悪全摘出群 } \\
(\mathrm{n}=20)\end{array}$ & $\begin{array}{c}\text { 全摘十自家移植 } \\
(\mathrm{n}=11)\end{array}$ & $\begin{array}{c}\text { total } \\
(n=31)\end{array}$ \\
\hline 高 PTH & 18 & 11 & 29 \\
\hline 高 Al-P & 19 & 9 & 28 \\
\hline 骨脱灰・吸収像 & 16 & 11 & 27 \\
\hline $\begin{array}{c}\text { 自 覚 症 状 } \\
\text { （骨・関節痛など） }\end{array}$ & 11 & 11 & 22 \\
\hline $\begin{array}{c}\text { 高 } \mathrm{Ca} \text { 血症 } \\
(>11 \mathrm{mg} / \mathrm{d} l)\end{array}$ & 5 & 3 & 8 \\
\hline $\begin{array}{c}\text { 画像診断 } \\
\mathrm{CT} \text {, echo, scinti }\end{array}$ & $11 / 11$ & 10 & $20 / 21$ \\
\hline
\end{tabular}

\section{表 2 腎性上皮小体機能六進症術前所見}

下となった後, Ca-gluconate, 乳酸 $\mathrm{Ca}, 1 \alpha \mathrm{OHD}_{3}$, によ り補充療法を開始した。以後血清 $\mathrm{Ca}$ 值を正常域に保つ ように投与量を調節した。移植腺生着確認のため，左右 时静脈にて c-PTH を経過を追って測定した。また $\mathrm{Al}$ -P, 骨 X線像にて術後の効果を判定した。

\section{結果}

典型例の術後経過を示す。図 1 は PT 21 の術後経過 表である。1981年 5 月 21 日に全摘出と自家移植術を施 行した。C-PTHは，術後急速に低下したが，術後20日 目よりほぼ一定となった。ほほ同日より移植側肘静脈の c-PTH は，他側より明らかに高值となり生着が確認さ れた。以後 c-PTH の再上昇の傾向はない。血清 $\mathrm{Ca}$ 值 は，術翌日には $7.0 \mathrm{mg} / \mathrm{d} l$ 以下となり, Ca-gluconate の 静注, 乳酸 $\mathrm{Ca}, 1 \alpha \mathrm{OHD}_{3}$ の内服を開始した。以後血清 $\mathrm{Ca}$ 値を見ながら投与量を調節し, 術後 4 力月以降は, $1 \alpha \mathrm{OHD}_{33} 0.5 \mu \mathrm{g} /$ day の内服のみで, 調節されている。 血清 $\mathrm{Pi}$ 值も術後急速に低下し, 術後 2 力月以降より徐久

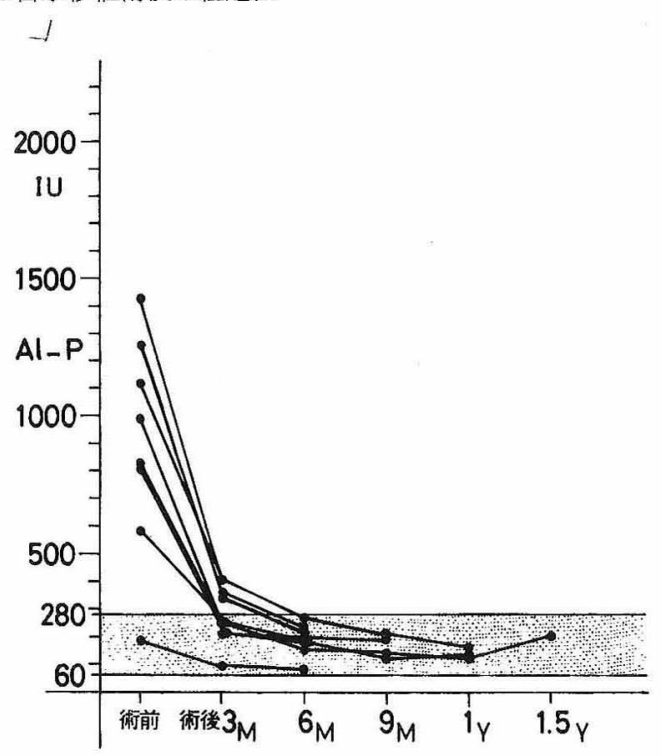

図2上皮小体全摘出と自家移植術後の $\mathrm{Al}-\mathrm{P}$

に上昇しているが，まだ Al-gel の投与は必要としてい ない。Al-Pは，術後一時上昇したが，以後すみやかに低 下し, 術後 3 力月目には正常域に入り, 以後再上昇して いない。

移植腺の生着の確認は, 左右肘静脈の PTH 值と血清 $\mathrm{Ca}$ 值によって判定し，全例 8〜28 日目に生着を確認し た。術後の低 $\mathrm{Ca}$ 血症は，西全摘出群に比し高度で，補 充療法も多量を要した。静注用 $\mathrm{Ca}$-gluconate $の$ 平均使 用量は亜全摘出群 $21.3 \mathrm{~g}(1 \mathrm{~A}=0.85 \mathrm{~g})$ に比し, $44.9 \mathrm{~g}$, 術 後 1 力月間の 1 日あたりの $1 \alpha \mathrm{OHD}_{3}$ 平均内服量は, 覀 全摘出群 $2.24 \mu \mathrm{g} /$ day に比し， $9.15 \mu \mathrm{g} /$ day であった。 術後 1 力月間の 1 日あたりの乳酸 $\mathrm{Ca}$ 平均内服量は，両 群とも $13.4 \mathrm{~g} /$ day と差はなかった（表 3 )。 


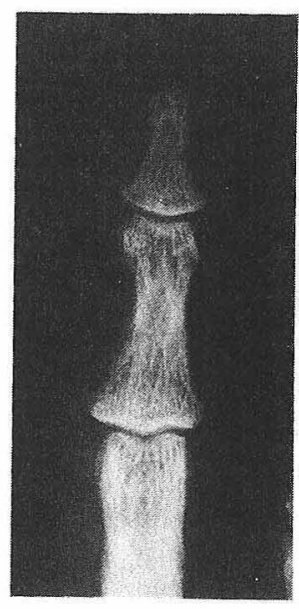

術 前

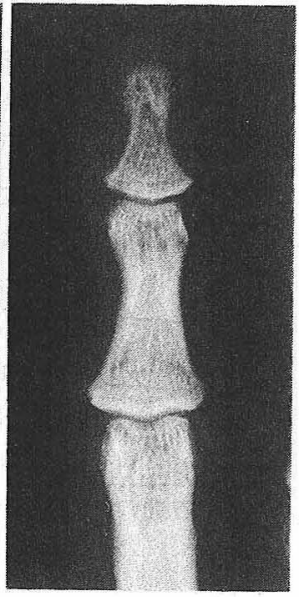

術後 3 力月

図 3 PT 28( ), 右手第 3 指骨X線写真。 術後, 骨膜下吸収像の明らかな改善が みられる

\begin{tabular}{r|c|c}
\hline & 亜全摘出術 & $\begin{array}{c}\text { 全摘出術 } \\
\text { 自家移植術 }\end{array}$ \\
\hline 例 数 & 20 & 11 \\
\hline $\begin{array}{r}\text { 平均全摘出重量 } \\
(\mathrm{mg})\end{array}$ & $2,672.0$ & $3,415.3$ \\
\hline $\begin{array}{r}\mathrm{Ca} \text { gluconate } \\
(\mathrm{A})\end{array}$ & 25.0 & 52.8 \\
\hline $\begin{array}{r}1 \alpha \cdot \mathrm{OH} \cdot \mathrm{D}_{3} \\
(\mu \mathrm{g} / \text { day }) 1 \mathrm{M}\end{array}$ & 2.24 & 9.15 \\
\hline $\begin{array}{r}\mathrm{Ca} \text { lactate } \\
(\mathrm{g} / \text { day }) 1 \mathrm{M}\end{array}$ & 13.4 & 13.4 \\
\hline
\end{tabular}

表 3 撤性上皮小体機能圥進症の外科手術

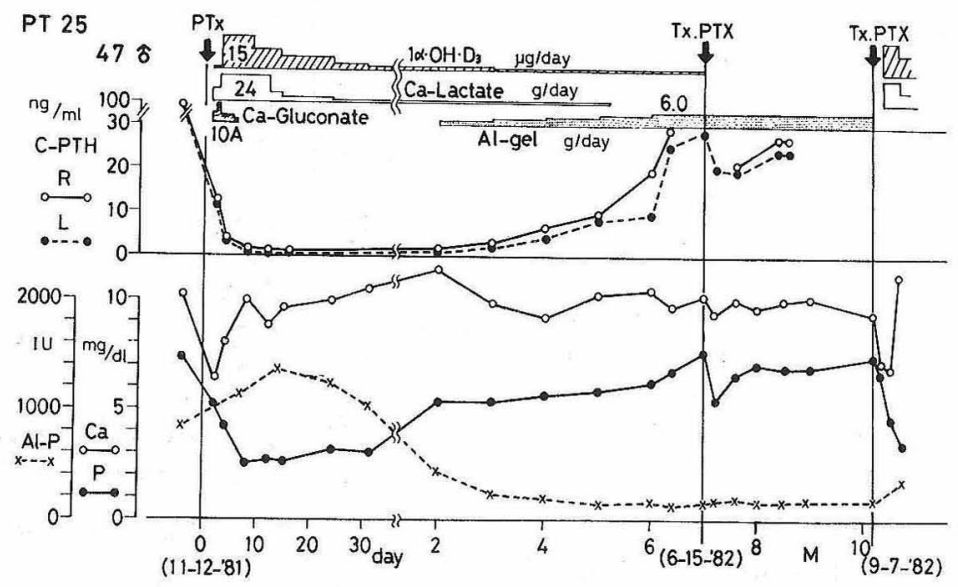

図 4 PT 25, 上皮小体全摘出と自家移植術後の経過表 (再発例)

Al-P の改善は, 図 2 のごとく顕著かつすみやかで あった。 8 例中 5 例は, 術後 3 力月以内に正常域まで低 下した. 残りの 3 例も術後 6 力月以内には正常域まで低 下した。術後 3 カ月目で Al-P が高值を示した 3 例は， いずれも骨所見が高度であった。全例再上昇の傾向はな い.骨X線像の改善も顕著かつすみやかであった。図 3 は PT 28 の術前と術後 3 力月の右手第 3 指のX線像で ある。術前に見られた高度の骨膜下吸収像は，すでに術 後 3 カ月で明らかな改善が見られた。自覚症状の改善も 顕著で, 術翌日には搔㾕感が消失し, 術後 1 週間以内よ り, 骨, 関節痛の改善が見られた。精神症状, 筋力低下 も明らかな改善が見られた。

平均全摘出重量は, 覀全摘出群 $2,672.0 \mathrm{mg}$ に対し, 全
摘と自家移植群 $3,415.3 \mathrm{mg}$ と重く術前所見の程度と一 致した (表 3 )。全摘と自家移植群 11 例の 44 腺は，すべ て過形成で， diffuse type $47.7 \%$ nodular type $52.3 \%$ で nodular type が若干多かった。構成細胞は, clear chief cell が主体であるが, dark chief cell, oxyphil cell, transitional oxyphil cell, vacuolated chief cell も混在 し, 多彩であった4)。

腎性上皮小体機能元進症の場合, 腎移植によって腎不 全が根本的に改善されない限り, 残存腺への刺激は避け られず，再発の可能性は大きい. PT 25 は，右前腕移植 腺の腫大による再発により，移植腺を摘出したので以下 に示す (図 4 )。1981 年 11 月 12 日上皮小体全摘出術と摘 出上皮小体の右前腕への自家移植術を施行した。摘出腺 


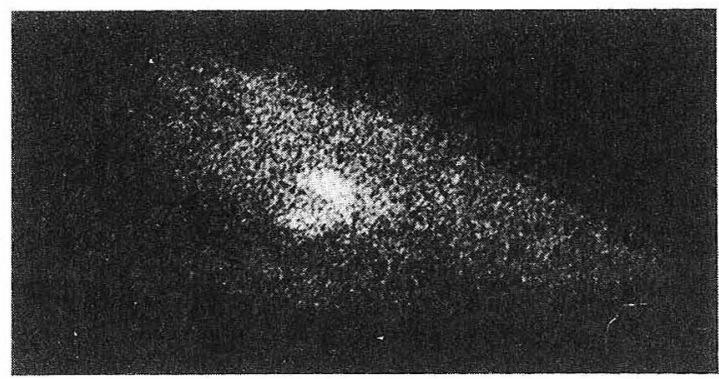

図 $5 \mathrm{PT} 25$, 術後 7 力月, 右前腕の ${ }^{201} \mathrm{TlCl}$ scintigram 像, 移植 腺への up take の亢進が見られる

は, $1 \times 1 \times 3 \mathrm{~mm}$ の小切片とし, 約 15 個を筋肉内に移植 した。摘出総重量は， $6220 \mathrm{mg}$ で，組織像は左上 $250 \mathrm{mg}$ の腺のみ diffuse type で, 残りの 3 腺は nodular type の過形成であった。構成細胞は， dark chief cell が主体 であるが，oxyphil cell, clear chief cell もかなりの量存 存していた。しかし分裂像, 被膜浸潤など悪性像はなかっ た。術後 c-PTH, 血清 $\mathrm{Ca}$ 值は著しく低下し，上皮小体 摘出効果は十分であった。移植腺の生着も術後 8 日目に は確認された。Al-P, 自覚症状，骨所見の改善も見られ た。しかし, 術後 3 力月目上り c-PTH は, 徐々に上昇 し, 術後 6 力月目には $1 \alpha \mathrm{OHD}_{3}$ の減量, $\mathrm{Al}$-gel の増量 にもかかわらず，血清 $\mathrm{Pi}$ が上昇し， $7.2 \mathrm{mg} / \mathrm{d} l$ にいたり, Al-gel の内服では調節困難となった。同時に術前と同様 な頑固な播痒感を訴えるようになった。右前腕移㥀部に は腫瘤を触れるようになり, 移植腺の腫大が考えられ た。 ${ }^{201} \mathrm{TlCl}$ scintigram を施行したところ，右前腕移植 部に一致して明らかな uptake の㠵進を認め, 移植腺腫 大による再発と診断した (図 5 )。1982 年 6 月 15 日，局 所麻酔下に右前腕より, $330 \mathrm{mg}$ と $394 \mathrm{mg}$ の著しく腫大 した移植上皮小体を摘出した。しかし, c-P'TH, 血清 $\mathrm{Ca}$, 血清 $\mathrm{Pi}$ 值の低下は十分でなく，同年 8 月に施行した ${ }^{201} \mathrm{TiCl}$ scintigram にても，移植腺の uptake が明らか であり,右前腕移植腺の摘出が不十分であると診断した。 そこで，同年 9 月 7 日局所麻酔下に再手術を施行し，約 $100 \mathrm{mg}$ の移植腺を残して, 確認でさた他の移植腺を全て 摘出した。摘出移植腺は, $1,420 \mathrm{mg}, 570 \mathrm{mg}, 530 \mathrm{mg}, 250$ $\mathrm{mg}, 240 \mathrm{mg}, 180 \mathrm{mg}$ の 6 個で総重量 $3,190 \mathrm{mg}$ と著しく 腫大していた。術後の血清 $\mathrm{Ca}$ 值の低下は著しく, 術翌々 日には $7 \mathrm{mg} / \mathrm{d} l$ 以下となり，摘出効果は十分であった。 摘出移植腺の組織像は，筋肉内に薄い被膜を形成してお り，多くは diffuse に腫大しているが，一部結節を形成 している移植腺も見られた。構成細胞は, clear chief cell が主体で一部 vacuolated chief cell への移行および混在 も見られ，chronic stimulationによる像と推察された。

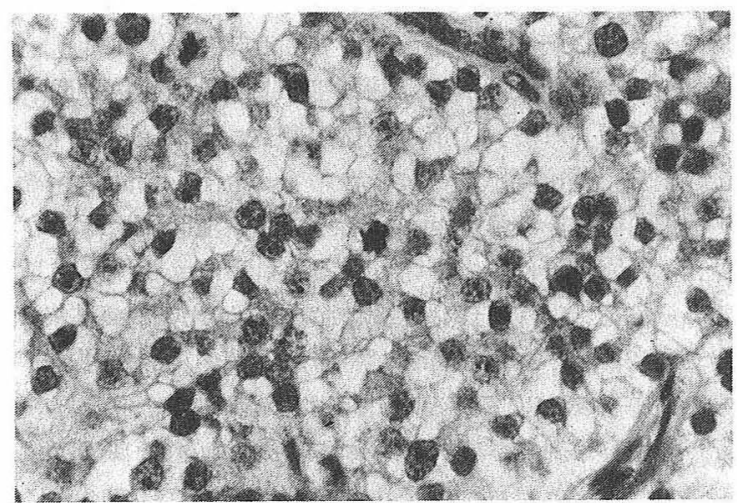

図 6 PT 25 摘出移植腺の組織像. Clear chief cell が主 体である。分裂像が中央と左上に見られる

分裂像も散見され著しい増植をしていることが窺われる が，核の大小不同は著しくなく，被膜への浸潤像も見ら れず，過形成と診断した（図 6 )。

考察

内科的治療に抵抗する高度な腎性上皮小体機能元進症 に対する外科的治療の必要性とその効果は，われわれを

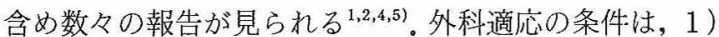
PTH 高值，2）Al-P 高值，3）骨X線像（骨脱灰吸収 像）４）自覚症状，が挙げられているが，実際には外科 適応決定困難な症例が存在する。腫大した上皮小体が， 術前確認できれば，診断はより確実となる。以前よりわ れわれは術前画像診断の有用性を報告してきだ,7)。500 $\mathrm{mg}$ 以上に腫大した上皮小体は，頸部 CT では約 $85 \%$ ， 頸部 echo では約 $75 \%,{ }^{201} \mathrm{TICl}$ と ${ }^{99 \mathrm{~m}} \mathrm{TcO}_{4}^{-}$scintigram と その subtraction 併用にて約 70\%が確認可能である。画 像診断導入後の上皮小体摘出例 21 例中 20 例までに, 術 前上皮小体の腫大の確認ができた。甲状腺腫陽に合併し た 1 例を除くと，20 例のそれぞれの摘出総重量は 1,000 $\mathrm{mg}$ 以上で西り，外科適応決定に扔ける，CT, echo, 
scintigramによる画像診断の有用性は大きい。また，術 後の経過観察にも画像診断は有用である。 ${ }^{201} \mathrm{TlCl}$ scintigram は頸部上皮小体の他に, 前腕の腫大した移植上皮 小体へも明らかな uptake の六進を示し, 前腕移植上皮 小体の再発診断にも有用であることが判明した。

腎性上皮小体機能六進症の術式としては, 従来より上 皮小体亚全摘出術あるいは全摘出術が施行されてきた。 全摘出術は, 術後上皮小体機能低下症となり, 特に術後 腎移植術を施行する場合は, 管理が非常に困難であり現 在ではほとんど施行されていない. 腎性上皮小体機能元 進症に対する上皮小体全摘出術と摘出上皮小体の前腕へ の自家移植術は, 1975 年 Wells 等の報告後 ${ }^{8}$, 諸家の報 告が続いている。以下本法の利点について検討を加える. 腎性上皮小体機能立進症の発症要因としては，1）リン の貯留，2）Vit D 代謝障害，3）PTH 反応性の低下 などが挙げられる。 上皮小体摘出後も, 腎移植を施行し ない限り, 腎不全状態は改善されず, 上記の要因は存続 する。再発は十分考慮せねばならない。衰全摘出術後の 再発は, Wilsonの他にも見られ8),われわれも 1 例経験し ている ${ }^{9}$. 上皮小体自家移植術後の再発は, Max 等 ${ }^{10)}$ で, 16 例中 2 例に, Diaz Buxo 等 ${ }^{11}$ は 50 例中に 3 例認め, 再手術を必要としている。方机われも 11 例中 1 例を経験 し, 術後 6 力月ですでに再手術を必要とし, 計 $3914 \mathrm{mg}$ の著しく腫大した移植上皮小体を摘出した。このように 腎性上皮小体機能立進症に対する上皮小体摘出術的, 常 に再発を念頭においてあたらなくてはならない. 再手術 に際しては, 亚全摘出後で頸部に残存した上皮小体摘出 術は, 手術侵襲が大きく, 術後の上皮小体機能低下症の 危険も大きい. 一方, 前腕移植腺の摘出は, 局所麻酔下 で施行でき, 手術も容易で, 手術侵襲も小さく, 摘出量 の調節も可能である. 残存腺の再発を防ぐためには, 残 存腺を少量にすれば良いとの考えから，亜全摘出術にお いて, Thomas の 15〜20 mg を残存させるべきだとの 主張もある ${ }^{12)}$. しかし, 著しく腫大した上皮小体から良好 な血行を温存させたまま, 極少量の上皮小体を残すこと は困難である。その点, 全摘と自家移植術では, 移植腺 の量の調節はきわめて容易である.Wells 等は $1 \times 1 \times 3$ $\mathrm{mm}$ の小切片を 15〜20 個 ${ }^{3)}$, Dietheln ${ }^{12}$ は, 4〜6 個 (20 〜30 mg) を移植するように主張している。われわれは， 当初 15〜20 個移植していたが, 再発例経験後は, 4 腺中 最も小さい，すなわち過形成の程度の最も軽い腺より 採った小切片を, 約 10 個移植している. 移植腺の機能発 現注, 術後 3〜7 日目 ${ }^{11}$ と, 10〜14 日目 ${ }^{3)}$ との報告がある. われわれの症例は, 術後 8〜28 日目であった. どの報告 も生着は, ほほ $100 \%$ でり, われわれの症例も全例生着 している. 生着は, ‘移植側と対側の PTH を測定し, 移
植側の PTH が有意に高值を示すことにより確認でき る。また, 同方法により, 移植腺の機能の状態を経過観 察できる. Geis ${ }^{13}$ の胸鎖乳突筋へ自家移植する方法は, 移 植腺よりのPTH 分泌の測定は困難である. 前腕への移 植は，血液透析のための blood access の作製に支障が あるので，胸鎖乳突筋への移植の方が良いとの報告があ る ${ }^{14)}$. しかし, blood access の作製予定部位を避けるこ とは困難ではなく, 移植腺よりの PTH 分泌測定, 再手 術の容易さを考えると前腕の方が, 移植部位としては適 していると考学る。移植腺が機能を発現しない場合，あ るいは生着後に線維化によって機能が廃絶した場合に は, 凍結保存した上皮小体の再移植が可能である ${ }^{15)}$.われ われも, 全例にて移植腺の一部を凍結保存している。凍 結保存の再移植例の経験はまだないが, 今後凍結保存腺 の viability 等検討を加えてゆきたいと考元ている。

\section{結論}

高度な腎性上皮小体機能充進症 11 例に, 上皮小体全摘 出術と摘出上皮小体の前腕筋肉内自家移植術を施行し た。全例生着し, 臨床的に著明な改善を見た。1例は再 発し, 局所麻酔下に腫大した移植腺を摘出した。本術式 は，1).再発時の摘出が容易，2）移植腺の量の調節が 可能，3）移植腺の機能の把握が可能などの点より, 再 発の可能性の十分存在する腎性上皮小体機能过進症の術 式として優れている。

\section{文献}

1) 高木 弘, 安江満悟, 森本剛史, 石井高博, 打田和 治, 山田宜夫, 冨永芳博, 浅井幹一, 両角国男, 山 崎親雄, 増子和郎, 川原弘久, 成田真康 : 腎性副甲 状腺機能穴進症に対する外科的治療. 日本外科学会 雑誌, 81 (8) : 791-801, 1980.

2) 高木 弘, 冨永芳博, 打田和治, 山田宜夫, 石井高 博, 森本剛史, 安江満悟, 加納忠行, 渡辺有三: 腎 性上皮小体機能立進症の診断と治療. 腎と透析 11 (3) : 295-302, 1981.

3) Samuel A. Wells, Jr., George S. Leight, Arthur J. Ross : primary hyperparathyroidism. Current Problems in Surgery XVII(8) : 451-457, 1980.

4）冨永芳博, 打田和治, 山田宜夫, 石井高博, 高木 弘, 安江満悟, 森本剛史, 加納忠行, 川原勝彦: 腎性上 皮小体機能无進症の手術と病理像. 第 82 回外科学会 総会発表, 千葉, 1982.

5）土居 真, 平林俊明, 依藤良一, 宮本 孝, 稲垣王 子, 森顈太郎, 下村林平, 井上聖士, 藤田嘉一, 申 曾洙, 有本保文, 大植春樹, 坂井瑠実, 西岡正登, 駒場啓太郎：腎性骨異栄養症に対する副甲状腺覀全 
摘術の適応と術後経過. 人工透析研究会会誌, 15 (1) : 39-44, 1982 .

6) 高木 弘, 冨永芳博, 石井高博, 打田和治, 山田宜 夫, 森本剛史, 安江満悟, 加納忠行, 川原勝彦: 腎 性骨異栄養症におりる上皮小体画像䛦断の意義につ いて。 日本外科学会雑誌，83(4)：352-356, 1982.

7) Hiroshi Takagi, Yoshihiro Tominaga, Kazuharu Uchida, Nobuo Yamada, Takahiro lshii, Takeshi Morimoto, and Mitsunori Yasue: Preoperative Diagnosis of Secondary Hyperparathyroidism Using Computed Tomography, J. Comput. Assit. Tomography 6 (3) : 527-528, June 1982.

8) Samuel A. Wells, Jr., J. Caulie Gunnells, John D. Sh'elburne, Arthur B. Schneider and Louis M. Sherwood M.D., : Transplantation of the parathyroid glands in man: Clinical indications and results, Surgery 78 (1) : 34-44, 1975.

9）富永芳博, 打田和治, 山田宜夫, 石井高博, 河合真 千夫, 高木 弘, 森本剛史, 安江満悟, 川原勝彦, 加納忠行：腎性上皮小体機能六進症に対する術式の 検討. 第 18 回中部外科学会総会発表, 金沢, 1982 .

10) Martin H. Max, Lewis M. Flint, J. David Richardson, Fred Z. Ferris, Deepak Nagar: Total parathyroidectomy and parathyroid autotransplantation in patients with chronic renal failure, Surg. Gyne. Obstet, $153: 177-180,1981$.
11) J. A. Diaz-Buxo, W. T. Geissinger, P. J. Walker, J. T. Chandler, C. D. Farmer, K. L. Holt and P. Wolfe : Total parathyroidectomy and autotransplantation, Clinical Nephrology 16(6) : 276-282, 1981.

12) Arnold G. Dietheln, Patricia L. Adams, Tariq M. Murad, William W. Daniel, John D. Whelchel, Edwin A. Rutsky, Stephen G. Rostand: Treatment of secondary hyperparathyroidism in patients with chronic renal failure by total parathy. roidectomy and parathyroid autograft. Ann. Surg. 193(6) : 777-793, 1981.

13) Geis, W. P., Popovtuz, M. M., Corman, J. L., et al. : The diagnosis and treatment of hyperparathyroidism after renal homotransplantation. Surg. Gyne. Obstet, 137, 997, 1973.

14) John F. Hayes, George F. Gross, Earl S. Schuman: Surgical Management of Renal Hyperparathyroidism in the Dialysis Patient. Am. J. Surg. $143:$ 569-571, 1982.

15) Samuel A. Wells, Jr. J. Caulie Gunnells, Robert A. Gutman, John D. Shelburne, Arthur B. Schneider and Louis M. Sherwood: The successful transplantation of frozen parathyroid tissue in man. Surgery 81 (1) : 86-90. 1977. 